\title{
Effect of hypoxia on the activity and binding of glycolytic and associated enzymes in sea scorpion tissues
}

V.I. Lushchak ${ }^{1,2}$

T.V. Bahnjukova ${ }^{2}$ and K.B. Storey ${ }^{3}$

\section{Correspondence}

V.I. Lushchak

Department of Medical Biology

and Genetics

Ivano-Frankivsk State

Medical Academy

Ivano-Frankivsk

Ukraine 28400

Received March 12, 1997

Accepted May 15, 1998

\author{
${ }^{1}$ Department of Medical Biology and Genetics, \\ Ivano-Frankivsk State Medical Academy, Ivano-Frankivsk, Ukraine \\ ${ }^{2}$ Karadag Branch of Southern Sea Biology Institute, \\ Kurortne, Feodosia, Crimea, Ukraine \\ Institute of Biochemistry and Department of Biology, Carleton University, \\ Ottawa, O ntario, Canada
}

\section{Abstract}

The effect of hypoxia on the levels of glycogen, glucose and lactate as well as the activities and binding of glycolytic and associated enzymes to subcellular structures was studied in brain, liver and white muscle of the teleost fish, Scorpaena porcus. Hypoxia exposure decreased glucose levels in liver from 2.53 to $1.70 \mu \mathrm{mol} / \mathrm{g}$ wet weight and in muscle led to its increase from 3.64 to $25.1 \mu \mathrm{mol} / \mathrm{g}$ wet weight. Maximal activities of several enzymes in brain were increased by hypoxia: hexokinase by $23 \%$, phosphoglucoisomerase by $47 \%$ and phosphofructokinase (PFK) by 56\%. However, activities of other enzymes in brain as well as enzymes in liver and white muscle were largely unchanged or decreased during experimental hypoxia. Glycolytic enzymes in all three tissues were partitioned between soluble and particulate-bound forms. In several cases, the percentage of bound enzymes was reduced during hypoxia; bound aldolase in brain was reduced from 36.4 to $30.3 \%$ whereas glucose-6-phosphate dehydrogenase fell from 55.7 to $28.7 \%$ bound. In muscle PFK was reduced from 57.4 to $41.7 \%$ bound. Oppositely, the proportion of bound aldolase and triosephosphate isomerase increased in hypoxic muscle. Phosphoglucomutase did not appear to occur in a bound form in liver and bound phosphoglucomutase disappeared in muscle during hypoxia exposure. Anoxia exposure also led to the disappearance of bound fructose-1,6-bisphosphatase in liver, whereas a bound fraction of this enzyme appeared in white muscle of anoxic animals. The possible function of reversible binding of glycolytic enzymes to subcellular structures as a regulatory mechanism of carbohydrate metabolism is discussed.

\section{Introduction}

Glycolytic and associated enzymes can bind reversibly to various cellular structures such as glycogen particles, F-actin, microfilaments (1-5) and membranes (6-8). These interactions can change some of their func-
Key words

- Fish

- Sea scorpion

- Hypoxia

- M etabolites

- Glycolytic enzyme binding
- Scorpaena porcus 
bution of enzymes between free and bound forms may, in turn, be modulated by changes in metabolite and ion levels $(6,12,13)$ or by reversible protein phosphorylation (3). Various studies on muscle have further assessed the possible existence of a glycolytic complex that could facilitate pathway flux by grouping together all of the glycolytic enzymes in a binding association with subcellular structural elements. The complex has never been conclusively documented experimentally, not surprising considering the weak nature of the binding contacts between enzymes and structural elements (14). Different attempts have been made to stabilize such a complex such as the addition of crowding agents to the extraction medium (e.g. polyethylene glycol) that should increase the stability of enzyme-enzyme interactions during their isolation $(14,15)$.

Although many questions about the functional consequences of glycolytic enzyme binding to the subcellular particulate fraction are not yet resolved, several researchers, using different techniques, have documented the redistribution of various enzymes between free and bound fractions as a function of changes in the physiological state of organisms. For instance, the percentage of glycolytic enzymes bound to subcellular particulate matter was altered in response to electrical stimulation of bovine muscle (16), anoxia in marine gastropods (17), or anoxia, hypoxia or exercise in fish $(11,18,19)$.

Exposure to hypoxia elicits multiple biochemical and physiological adjustments in fish tissues $(20,21)$. Immediate responses include an activation of anaerobic glycolysis and the breakdown of creatine phosphate which increase ATP production at a time when mitochondrial oxidative phosphorylation is limited by oxygen availability. Over the longer term physiological and biochemical adjustments occur which improve the ability to extract oxygen from hypoxic water or reduce the animal's dependence on oxygen, if hypoxia is severe. The latter adjust- ments can include a switch to specific fermentative pathways that have advantages over anaerobic glycolysis alone or the initiation of metabolic rate depression so that cellular energy demands are sharply suppressed and coordinated with the reduced rates of anaerobic ATP production (21).

It is evident that the glycolytic pathway is central to hypoxia survival in fish. Although the response of the pathway under hypoxia has been extensively investigated (22-28), the mechanisms which provide the metabolic adaptation are still not fully understood. Certainly, these processes are highly coordinated and many mechanisms such as allosteric effects of metabolites, reversible protein phosphorylation, and enzyme binding interactions with cellular structural elements may participate in the control of the overall response to hypoxia (29). The last mechanism, enzyme binding, remains poorly studied. The present study was designed to further investigate the effects of hypoxia exposure on the distribution of enzymes between free and particulate-bound fractions in tissues of teleost fish and to assess the effects that such changes may have on carbohydrate metabolism under hypoxia.

\section{Material and Methods}

\section{Experimental animals}

Sea scorpions (Scorpaena porcus L.) weighing 120-400 g were caught in JuneJuly 1995 at Karadag Bay, Black Sea (Crimea, Ukraine) and were held in tanks provided with flowing sea water and the native dark/ light cycle at a temperature of $20-21^{\circ} \mathrm{C}$. Fish were not fed and were used the next day.

\section{Biochemicals and coupling enzymes}

All chemicals were obtained from Boehringer Mannheim, Montreal, PQ; Sigma Chemical Co., St. Louis, MO, and Reachim (USSR). 


\section{Exposure to hypoxia}

A continuous-flow system was used for the experiments. Fish were placed in a 10liter experimental chamber equipped with a water pump. This chamber was placed in a larger aquarium that was stabilized at $20.6 \pm$ $1.0^{\circ} \mathrm{C}$. The temperature and oxygen levels were monitored with a two-channel oxymeter purchased from Sigma (Charkiv, Ukraine). Electrodes were calibrated to zero oxygen with a freshly prepared $2 \%$ sodium persulfate solution. Calibration to $100 \%$ was done with air.

Eight fish were carefully transferred from the tanks into the chamber at about 6:007:00 a.m. and held there for $1 \mathrm{~h}$ at $100 \%$ oxygen saturation. After this, four fish were sampled as controls and then the chamber was closed. The level of oxygen was allowed to gradually decrease over $90-120 \mathrm{~min}$ to $15 \%$ saturation as the result of its consumption by the fish. When the desired oxygen concentration was reached, this level was stabilized by bubbling air through the chamber and a constant $15 \%$ saturation was maintained over the subsequent $90 \mathrm{~min}$.

\section{Tissue sampling}

Fish from the chamber were placed into a bucket with water from the chamber and sacrificed within $20 \mathrm{~min}$. No essential differences in enzyme parameters were found between the first and the last animal in a group. The procedure from removal of the fish from the bucket through killing by spinal dissection, removal of tissue samples, and preparation of tissue homogenate took about 2 min. Whole brain and portions of the liver and white muscle were used for analysis. White muscle samples were removed from the body below the first spinal fin.

\section{Metabolite extraction}

For the analysis of glycogen, glucose and lactate, tissue extraction was performed in a "Potter-Elvehjam" homogenizer in 10-50 volumes of $60 \%$ ethanol, containing $8 \%$ perchloric acid (23). This procedure separates glycogen in the sediment after centrifugation whereas glucose and lactate remain in the supernatant (23). Glycogen in the precipitate and glucose in the supernatant were determined by the anthrone method whereas lactate was quantified enzymatically (30).

\section{Enzyme studies}

Excised fresh tissues were quickly washed in ice-cold $0.9 \% \mathrm{NaCl}$, blotted on filter paper, weighed and homogenized in a "PotterElvehjam" homogenizer in 10 volumes of homogenization solution of the following composition: $0.25 \mathrm{M}$ sucrose, $10 \mathrm{mM}$ dithiothreitol (DTT), $20 \mathrm{mM} \mathrm{NaF}, 1 \mathrm{mM}$ EDTA, $20 \mathrm{mM}$ imidazole- $\mathrm{HCl}, \mathrm{pH} 7.0$ at $20^{\circ} \mathrm{C}$, and a few crystals of the protease inhibitor phenylmethylsulfonyl fluoride. The homogenate was centrifuged for $20 \mathrm{~min}$ at $45,000 \mathrm{~g}$ at $4^{\circ} \mathrm{C}$ and the supernatant was then removed and stored on ice. Enzyme activity in this supernatant represents the free enzyme fraction. The pellet was rehomogenized in 5 volumes (relative to initial tissue weight) of the following solution containing high salt to release bound enzymes: $0.25 \mathrm{M}$ sucrose, $10 \mathrm{mM}$ DTT, $20 \mathrm{mM} \mathrm{NaF}, 1 \mathrm{mM}$ EDTA, $20 \mathrm{mM}$ imidazole-HCl, pH 7.0 at $20^{\circ} \mathrm{C}$, and $500 \mathrm{mM} \mathrm{KCl}$. After centrifugation, the supernatant was removed and the pellet was then extracted a second time and centrifuged and the second supernatant was combined with the first. Enzyme activity in this fraction represents the bound enzyme fraction. Maximal enzyme activities were quantified in both free and bound fractions and the percentage of activity in the bound fraction was calculated using the following formula: bound/(bound + free) $\times 100$. Recovery of total enzyme activity was checked in all cases by comparing the sum of enzyme activities in free and bound fractions with 
enzyme activities measured in tissue homogenates; recovery was close to $100 \%$ in most case, ranging from $80-120 \%$.

Enzyme activities were assayed at $25^{\circ} \mathrm{C}$ using a KFK-324 spectrophotometer (LOMO, Leningrad, USSR) by monitoring the change in absorbance of NADH or $\mathrm{NADPH}$ at $340 \mathrm{~nm}$. The activity of each enzyme was determined in four independently prepared supernatants of extracts from tissues of four individual fish. All reaction mixtures contained $50 \mathrm{mM}$ imidazole- $\mathrm{HCl}$, $\mathrm{pH} 7.0$ at $25^{\circ} \mathrm{C}$, and the final volume was 1.0 $\mathrm{ml}$ including added extract. Blanks were run in all cases that omitted the most specific substrate (indicated by an asterisk in the assays below). In initial tests, reactions were started by addition of the most specific substrate, but if no blank was found, further assays were started by the addition of enzyme extract. Optimal assay conditions were based on those described earlier (31) and adapted for our experiments.

Enzymes were assayed under the following conditions: hexokinase (HK; EC 2.7.1.1): $10 \mathrm{mM}$ glucose*, $0.2 \mathrm{mM}$ NADP, $2 \mathrm{mM}$ ATP, $5 \mathrm{mM} \mathrm{MgCl} 2,0.5$ unit (U) glucose-6phosphate dehydrogenase (G6PDH), and 30-

Table 1 - Effect of hypoxia on metabolites associated with carbohydrate metabolism in sea scorpion tissues.

Data are reported as means \pm SEM $(\mathrm{N}=4)$. Values are $\mu \mathrm{mol} / \mathrm{g}$ wet weight with glycogen expressed as glucose units. ap $<0.005$, bP $<0.001$ compared to control (Student t-test).

\begin{tabular}{llcc}
\hline Tissue & Metabolite & Control & Hypoxia \\
\hline Brain & Glycogen & $9.69 \pm 2.85$ & $7.72 \pm 2.30$ \\
& Glucose & $1.65 \pm 0.01$ & $1.72 \pm 0.33$ \\
& Lactate & $1.15 \pm 0.07$ & $1.47 \pm 0.16$ \\
Liver & Glycogen & $73.3 \pm 7.4$ & $64.3 \pm 18.1$ \\
& Glucose & $2.53 \pm 0.16$ & $1.70 \pm 0.03^{3}$ \\
& Lactate & $0.32 \pm 0.05$ & $0.26 \pm 0.02$ \\
Muscle & Glycogen & $25.0 \pm 4.3$ & $17.1 \pm 2.6$ \\
& Glucose & $3.64 \pm 0.44$ & $25.1 \pm 1.4^{b}$ \\
& Lactate & $0.50 \pm 0.02$ & $0.70 \pm 0.12$
\end{tabular}

$50 \mu$ supernatant. Phosphoglucoisomerase (PGI; EC 5.3.1.9): $2.5 \mathrm{mM}$ fructose-6-phosphate*, $0.2 \mathrm{mM}$ NADP, $5 \mathrm{mM} \mathrm{MgCl}_{2}, 0.5 \mathrm{U}$ G6PDH, and $5 \mu 1$ supernatant. Phosphofructokinase (PFK; EC 2.7.1.11): $5 \mathrm{mM}$ fructose-6-phosphate*, $5 \mathrm{mM}$ ATP, $0.15 \mathrm{mM}$ $\mathrm{NADH}, 10 \mathrm{mM} \mathrm{MgCl} 2,50 \mathrm{mM} \mathrm{KCl}, 0.5 \mathrm{U}$ aldolase, $0.5 \mathrm{U}$ triosephosphate isomerase, 2 U glycerol-3-phosphate dehydrogenase, and 30-50 $\mu \mathrm{l}$ supernatant. Aldolase (Ald; EC 4.1.2.13): $0.5 \mathrm{mM}$ fructose-1,6-bisphosphate*, $0.15 \mathrm{mM}$ NADH, $0.5 \mathrm{U}$ triosephosphate isomerase, $2 \mathrm{U}$ glycerol-3-phosphate dehydrogenase, and 5-10 $\mu \mathrm{l}$ supernatant. Triosephosphate isomerase (TPI; EC 5.3.1.1): $4 \mathrm{mM}$ glyceraldehyde-3-phosphate*, 0.15 mM NADH, 0.5 U glycerol-3-phosphate dehydrogenase, and 30-50 $\mu 1$ supernatant. Pyruvate kinase (PK; EC 2.7.1.40): $10 \mathrm{mM}$ phosphoenolpyruvate*, $2.5 \mathrm{mM}$ ADP, $50 \mathrm{mM}$ $\mathrm{KCl}, 5 \mathrm{mM} \mathrm{MgCl}, 0.15 \mathrm{mM} \mathrm{NADH}, 0.5 \mathrm{U}$ lactate dehydrogenase, and 5-10 $\mu 1$ supernatant. Lactate dehydrogenase (LDH; EC 1.1.1.27): $1 \mathrm{mM}$ pyruvate*, $0.15 \mathrm{mMNADH}$, $1 \mathrm{mM}$ EDTA, and 5-20 $\mu 1$ supernatant. Glucose-6-phosphate dehydrogenase (G6PDH; EC 1.1.1.49): 2.0 mM glucose-6-phosphate*, $5 \mathrm{mM} \mathrm{MgCl}_{2}, 0.2 \mathrm{mM}$ NADP, and 10-50 $\mu \mathrm{l}$ supernatant. Phosphoglucomutase (PGM; EC 2.7.5.1): $15 \mathrm{mM}$ glucose-1-phosphate*, 0.20 mM NADP, $5.0 \mathrm{mM} \mathrm{MgCl} 2,0.5 \mathrm{U}$ G6PDH, and 10-30 $\mu \mathrm{l}$ supernatant. Fructose-1,6bisphosphatase (FBPase; EC 3.1.3.11): 0.1 $\mathrm{mM}$ fructose-1,6-bisphosphate*, $0.2 \mathrm{mM}$ NADP, $5 \mathrm{mM} \mathrm{MgCl}$, $0.5 \mathrm{U}$ G6PDH, $0.5 \mathrm{U}$ phosphoglucoisomerase, and 10-50 $\mu 1$ supernatant.

One unit of enzyme activity was defined as the amount of enzyme which converts 1 $\mu \mathrm{mol}$ of substrate per minute at $25^{\circ} \mathrm{C}$ (IU). All values are reported as mean \pm SEM. Differences between the means were estimated by the two-tailed Student $t$-test.

\section{Results}

Table 1 shows the effect of hypoxia on 
the levels of glycogen, glucose and lactate in three tissues of the sea scorpion: brain, liver and white muscle. Glycogen levels were highest in the liver and lowest in the brain. Exposure of fish to water with $15 \%$ oxygen saturation for $90 \mathrm{~min}$ did not significantly change the glycogen content of any tissue, although a definite trend to reduced mean glycogen levels after hypoxia was observed in all instances. Effects of hypoxia exposure on glucose levels were different in each tissue. In the brain, glucose was unaltered after hypoxia exposure whereas in hypoxic liver glucose decreased by $33 \%$. By contrast, hypoxia led to a 6.9-fold increase in the glucose content of white skeletal muscle. The concentration of lactate in sea scorpion tissues was very low in all cases and was not changed after hypoxia exposure. The low lactate levels were consistent with a low activity level (and a possible metabolic depression) of the fish being observed during experimental hypoxia; after 30-40 min of hypoxia exposure the fish had lost their righting response and did not struggle when removed from the water. Since enzymes are responsible for the regulation of metabolic rate in organisms, we studied the effect of hypoxia on the activity of some glycolytic and other associated enzymes.

Hypoxia exposure altered both the maximal activities of some enzymes and the distribution of enzymes between free and bound forms in sea scorpion tissues. In the brain, the maximal activities of three enzymes were significantly elevated during hypoxia: HK by $23 \%$, PGI by $47 \%$ and PFK by $56 \%$ (Table 2). However, in the liver only one hypoxia-induced change in enzyme activity was observed, i.e., a $17 \%$ decrease in PFK (Table 3). In white muscle hypoxia exposure resulted in a $27 \%$ decrease in PGI activity but a $64 \%$ increase in LDH (Table 4 ).

A high variation in the percentages of enzymes bound to subcellular particulate matter was found in sea scorpion tissues. In the liver, for example, about $60-65 \%$ of TPI
Table 2 - Effect of hypoxia on the maximal activities of enzymes of carbohydrate metabolism and percentage of these activities bound to the subcellular particulate fraction in sea scorpion brain.

Data are reported as means \pm SEM $(N=4)$. aP $<0.05$, bP $<0.005$ compared to control (Student t-test). HK, Hexokinase; PGI, phosphoglucoisomerase; PFK, phosphofructokinase; Ald, aldolase; TPI, triosephosphate isomerase; PK, pyruvate kinase; LDH, lactate dehydrogenase; G6PDH, glucose-6-phosphate dehydrogenase; PGM, phosphoglucomutase; FBPase, fructose-1,6-bisphosphatase.

\begin{tabular}{|c|c|c|c|c|}
\hline \multirow[t]{2}{*}{ Enzyme } & \multicolumn{2}{|c|}{ Activity $\left(\mu \mathrm{mol} \mathrm{min}^{-1} \mathrm{~g}^{-1}\right)$} & \multicolumn{2}{|c|}{ Bound enzyme (\%) } \\
\hline & Control & Hypoxia & Control & Hypoxia \\
\hline HK & $0.78 \pm 0.04$ & $0.96 \pm 0.06^{a}$ & $49.2 \pm 2.3$ & $54.2 \pm 2.9$ \\
\hline PGI & $25.0 \pm 1.2$ & $36.8 \pm 1.0^{b}$ & $34.3 \pm 2.5$ & $35.4 \pm 2.0$ \\
\hline PFK & $1.60 \pm 0.28$ & $2.50 \pm 0.04^{a}$ & $38.8 \pm 5.5$ & $26.4 \pm 3.1$ \\
\hline Ald & $4.68 \pm 0.32$ & $4.07 \pm 0.23$ & $36.4 \pm 2.2$ & $30.3 \pm 1.0^{a}$ \\
\hline TPI & $1.83 \pm 0.16$ & $1.67 \pm 0.12$ & $47.2 \pm 4.5$ & $46.9 \pm 4.0$ \\
\hline PK & $39.3 \pm 0.6$ & $41.8 \pm 1.1$ & $26.3 \pm 3.0$ & $26.3 \pm 2.1$ \\
\hline LDH & $22.0 \pm 1.4$ & $24.5 \pm 1.6$ & $24.2 \pm 1.6$ & $22.4 \pm 1.4$ \\
\hline G6PDH & $0.37 \pm 0.05$ & $0.43 \pm 0.04$ & $55.7 \pm 5.3$ & $28.7 \pm 3.0^{a}$ \\
\hline PGM & $0.44 \pm 0.03$ & $0.56 \pm 0.08$ & $24.0 \pm 3.0$ & $23.0 \pm 2.7$ \\
\hline FBPase & $3.12 \pm 0.69$ & $2.43 \pm 0.28$ & $31.2 \pm 9.1$ & $39.1 \pm 5.8$ \\
\hline
\end{tabular}

Table 3 - Effect of hypoxia on the maximal activities of enzymes of carbohydrate metabolism and the percentage of these activities bound to the subcellular particulate fraction in sea scorpion liver.

Data are reported as means \pm SEM $(N=4)$. aP $<0.05$, bP $<0.005$ compared to control (Student t-test). N.F., Not found. See Table 2 for explanation of abbreviations.

\begin{tabular}{|c|c|c|c|c|}
\hline \multirow[t]{2}{*}{ Enzyme } & \multicolumn{2}{|c|}{ Activity $\left(\mu \mathrm{mol} \mathrm{min}^{-1} \mathrm{~g}^{-1}\right)$} & \multicolumn{2}{|c|}{ Bound enzyme (\%) } \\
\hline & Control & Hypoxia & Control & Hypoxia \\
\hline HK & $1.48 \pm 0.20$ & $1.42 \pm 0.29$ & $9.7 \pm 1.7$ & $26.6 \pm 2.7^{b}$ \\
\hline PGI & $18.9 \pm 1.0$ & $20.8 \pm 0.9$ & $30.9 \pm 5.6$ & $38.1 \pm 1.4$ \\
\hline PFK & $3.91 \pm 0.24$ & $3.23 \pm 0.12^{a}$ & $55.4 \pm 1.6$ & $50.4 \pm 1.8$ \\
\hline Ald & $4.11 \pm 0.42$ & $3.54 \pm 0.22$ & $32.2 \pm 2.8$ & $32.1 \pm 3.4$ \\
\hline TPI & $0.81 \pm 0.08$ & $0.47 \pm 0.08$ & $61.0 \pm 0.7$ & $66.8 \pm 7.9$ \\
\hline PK & $5.08 \pm 0.27$ & $7.34 \pm 0.95$ & $39.9 \pm 2.0$ & $32.3 \pm 3.4$ \\
\hline LDH & $1.95 \pm 0.16$ & $1.70 \pm 0.07$ & $44.1 \pm 2.6$ & $49.7 \pm 4.6$ \\
\hline G6PDH & $5.61 \pm 0.72$ & $4.95 \pm 0.20$ & $17.0 \pm 2.7$ & $11.6 \pm 1.4$ \\
\hline PGM & $1.33 \pm 0.28$ & $1.24 \pm 0.30$ & N.F. & N.F. \\
\hline FBPase & $2.21 \pm 0.35$ & $1.77 \pm 0.26$ & $5.3 \pm 4.6$ & N.F. \\
\hline
\end{tabular}


was bound, whereas only $0-5 \%$ of FBPase was found in this state (Table 3 ). None of the PGM in liver was associated with the particulate fraction and bound FBPase in liver and PGM in muscle could not be detected in hypoxic tissues. Selected enzymes in each tissue showed significant changes in the percentage of activity in the bound fraction as the result of hypoxia exposure. In the brain, the percentage of bound Ald decreased and bound G6PDH fell by nearly half (Table 2). In hypoxic liver the percentage of bound HK increased by 2.7 -fold, whereas all FBPase activity disappeared from the bound fraction (Table 3). In white muscle hypoxia exposure led to a reduced percentage of bound PFK and the disappearance of bound FBPase, whereas the percentages of bound Ald and TPI increased (Table 4).

\section{Discussion}

Although alien to the physiology of man, a facility for metabolic depression occurs widely in nature. Metabolic depression is a key factor in facultative anaerobiosis, anhydrobiosis, hibernation, estivation, torpor and

\begin{tabular}{|c|c|c|c|c|}
\hline \multirow[t]{2}{*}{ Enzyme } & \multicolumn{2}{|c|}{ Activity $\left(\mu \mathrm{mol} \mathrm{min}^{-1} \mathrm{~g}^{-1}\right)$} & \multicolumn{2}{|c|}{ Bound enzyme (\%) } \\
\hline & Control & Hypoxia & Control & Hypoxia \\
\hline HK & $0.51 \pm 0.05$ & $0.39 \pm 0.04$ & $22.7 \pm 4.0$ & $25.3 \pm 3.1$ \\
\hline PGI & $16.6 \pm 1.4$ & $12.1 \pm 0.6^{a}$ & $35.1 \pm 3.5$ & $45.3 \pm 4.8$ \\
\hline PFK & $2.81 \pm 0.16$ & $3.38 \pm 0.20$ & $57.4 \pm 2.3$ & $41.7 \pm 1.8^{b}$ \\
\hline Ald & $20.5 \pm 0.6$ & $20.9 \pm 1.8$ & $17.1 \pm 1.5$ & $27.8 \pm 1.0^{\mathrm{b}}$ \\
\hline TPI & $0.95 \pm 0.11$ & $1.01 \pm 0.04$ & $48.6 \pm 3.6$ & $64.4 \pm 1.1^{b}$ \\
\hline PK & $124.0 \pm 8.0$ & $117.0 \pm 12.0$ & $18.5 \pm 1.2$ & $18.8 \pm 2.6$ \\
\hline LDH & $55.1 \pm 9.7$ & $90.6 \pm 2.7^{a}$ & $28.9 \pm 7.3$ & $12.6 \pm 2.6$ \\
\hline G6PDH & N.F. & N.F. & N.F. & N.F. \\
\hline PGM & $1.88 \pm 0.14$ & $1.72 \pm 0.11$ & $16.7 \pm 2.4$ & N.F. \\
\hline FBPase & $0.26 \pm 0.03$ & $0.29 \pm 0.04$ & N.F & $7.0 \pm 6.1$ \\
\hline
\end{tabular}

diapause. It allows organisms to economize on fuel and energy reserves in the face of environmental stress of unpredictable duration $(29,32)$. The theory of metabolic depression applies well to fish in hypoxic or anoxic states. A drop in the contribution of oxidative phosphorylation to energy production and an enhancement of the anaerobic contribution are well documented but are often accompanied by an overall suppression of net ATP turnover that helps to conserve fuel use when inefficient fermentative pathways are the primary source of ATP (for reviews see 20,21,29). Therefore, the role of the glycolytic pathway in these states is critical.

The trend towards reduced glycogen levels in all three tissues during hypoxia as well as significant changes in glucose in liver and muscle were consistent with altered carbohydrate metabolism in hypoxic tissues (Table 1). In particular, glucose concentration rose 6.9-fold in muscle. Although lactate did not accumulate, the animals were clearly energy stressed, as shown by their loss of equilibrium and lack of muscle tone. Tissue specific changes in the levels of these and other glycolytic metabolites during hypoxia/anoxia exposure support the central role of glycolysis in metabolic ATP production at low oxygen levels in various other fish species including the Crucian carp Carassius carassius (22), European eel Anguilla anguilla (28), flounder Platichthys flesus $(23,24)$ and red mullet Mullus barbatus (25). For instance, in red mullet the level of metabolites in the brain was not changed by 90 -min exposure to water with $50 \%$ oxygen saturation, but in the liver glycogen and glucose concentrations were decreased about 3-fold (25).

The variation in maximal enzyme activities in the three tissues (Tables 2-4) correlates well with tissue function. For example, the high activities of most glycolytic enzymes in white muscle is associated with their use in supporting burst swimming for food capture, whereas activities of enzymes 
involved in biosynthetic processes, such as G6PDH and FBPase, were either undetectable or low in muscle. On the contrary, the liver showed substantial activities of both of these enzymes but lower overall activities of glycolytic enzymes.

It should be noted that the maximal activities of glycolytic enzymes in sea scorpion tissues were generally rather low compared with other animals and fish. This fact may be related to the low physical activity of this species. Sea scorpions spend much of their time motionless with infrequent bursts of activity for prey capture. It is possible that for such short bursts of activity ATP derived from creatine phosphate hydrolysis may be sufficient to support muscle work and that phosphagen would subsequently be slowly restored later.

Increased maximal activities of the key glycolytic enzymes, HK and PFK, in the brain correlate well with the known strong reliance of brain on glucose as its primary metabolic fuel, a reliance that would be further enhanced during hypoxia. The increases in these key activities may support increased glycolytic flux when oxygen-based metabolism is restricted. In contrast, a small reduction in PFK activity in the liver during hypoxia may be consistent with a primary function of this organ in glucose export during hypoxia in order to provide fermentative fuel to other organs. The primary effect of hypoxia on skeletal muscle, a strong increase in LDH activity, may be a precursor for increased glycolytic ATP production.

Information on the effects of hypoxia or anoxia on the activities of glycolytic and associated enzymes in fish tissues is quite limited. Previous studies showed that anoxia resulted in a redistribution of glycogen phosphorylase between $\underline{a}$ and $\underline{b}$ forms as well as changes in the content of fructose-2,6-bisphosphate in goldfish tissues (33). These data, taken together with kinetic constants for PFK measured in different tissues, led us to conclude that PFK represents a major control point for coordinating changes in carbohydrate metabolism in response to changes in the physiological state of animals and that the mechanism of this change includes the reversible phosphorylation of the enzyme as well as modification of the levels of the PFK allosteric activator, fructose-2,6bisphosphate. Short-term hypoxia activated PFK in the brain and liver and HK in the brain of red mullet but had no effect on PK activity in either tissue (25). Long-term hypoxia (1.5 months) modified the activities of some glycolytic enzymes in goldfish tissues (34). Clearly, short- and long-term hypoxia or anoxia can differently affect the enzymes of carbohydrate metabolism in fish.

Hypoxia exposure significantly changed the distribution of various enzymes between free and particulate-bound states in sea scorpion tissues. Such a redistribution indicates that this mechanism may be involved in the regulation of glycolysis in these organs, providing space-time compartmentation of the pathway to serve different metabolic needs. The specific enzymes affected in different tissues could result in tissue-specific changes in flux through different pathways in a manner that serves the metabolic needs of each organ. In the brain, for example, a strong decrease in the percentage of G6PDH bound under hypoxic conditions may have a major effect on flux through the pentose phosphate shunt and on the relative consumption of glucose-6-phosphate by this pathway versus glycolysis. In the liver, the 3-fold increase in the amount of bound HK may be the key to supporting increased glucose utilization as a substrate for the hypoxic organ. A reduction in the percentage of bound PFK in skeletal muscle contrasts with an exercise-induced increase in bound PFK in trout muscle during glycolysis-fueled muscle work (14) and suggests that the hypoxic muscle of sea scorpion may exhibit a metabolic depression that actually lowers the glycolytic rate. Factors influencing the redistribution of enzymes could include several that might be due to 
the effects of hypoxia on cellular metabolism including a change in intracellular $\mathrm{pH}$, changes in the levels of different metabolites, or reversible enzyme phosphorylation. As other studies have shown, free and bound enzymes can also differ in their stability $(7,10,11)$ and changes in the percentage of bound enzyme could also affect the structural stability and/or the turnover rate of enzymes under stresses that alter physical conditions in the cytosol. In addition to different kinetic properties of free and bound enzymes (35), their redistribution may be an effective mechanism allowing animals to adapt to environmental changes.

The nature of the structural elements to which enzymes may bind can also be discussed. For example, in the brain, glycolytic enzymes may be associated with mitochondria or the cytoskeleton proteins, actin and tubulin $(10,15)$, whereas in the liver association with the endoplasmic reticulum has been documented (8). In muscle, PFK interacts with actin (1-5) (as do other glycolytic en- zymes) and binding is altered by the phosphorylation state of the enzyme (3). In muscle, $\mathrm{LDH}$ is also found to be associated with the membrane of the sarcoplasmic reticulum $(10,13)$. Because various structural elements may be involved as subcellular sites for enzyme binding, this provides yet another mechanism for the differential control of enzymes and the pathways to which they belong. The possibility of formation of supramolecular complexes also cannot be ignored in this discussion. Although the interaction of some enzymes with structural elements reduced their activity, their association in a complex might result in a net increase in pathway flux through a multienzyme complex as a consequence of an increase in the local concentration of metabolites $(10,14,15,19,35)$.

\section{Acknowledgments}

The authors thank J.M. Storey for critical commentary on the manuscript and L.M. Rudenko for skillful technical assistance.

\section{References}

1. Kuo H- , Malencik DA, Liou R-S \& Anderson SR (1986). Factors affecting the activation of rabbit muscle phosphofructokinase by actin. Biochemistry, 25: 12781286.

2. Liou R-S \& Anderson S (1980). Activation of rabbit muscle phosphofructokinase by F-actin and reconstituted thin filaments. Biochemistry, 19: 2684-2688.

3. Luther MA \& Lee JC (1986). The role of phosphorylation in the interaction of rabbit muscle phosphofructokinase with $\mathrm{F}$ actin. J ournal of Biological Chemistry, 261: 1753-1759.

4. Roberts SJ \& Somero GN (1987). Binding of phosphofructokinase to filamentous actin. Biochemistry, 26: 3437-3442.

5. Roberts SJ \& Somero GN (1989). Properties of the interaction between phosphofructokinase and actin. Archives of Biochemistry and Biophysics, 269: 284-294.

6. Hsu SC \& Molday RS (1990). Glyceraldehyde-3-phosphate dehydrogenase is a major protein associated with the plasma membrane of retinal photoreceptor outer segments. J oumal of Biological Chemistry, 265: 13308-13313.

7. Lushchak VI (1992). Free and membranebound lactate dehydrogenase from white driving muscles of skate. Biochemistry Intemational, 26: 905-912.

8. Sagrista ML \& Bozal J (1987). Lactate and malate dehydrogenase binding to the microsomal fraction from chicken liver. Biochemistry, 69: 1207-1215.

9. Ehmann J D \& Hultin HO (1973). Substrate inhibition of soluble and bound lactate dehydrogenase (isoenzyme 5). Archives of Biochemistry and Biophysics, 154: 471475.

10. Lushchak VI (1992). Lactate dehydrogenase interaction with the structural cell components: the possible physiological significance. Biokhimiya, 57: 1142-1154.

11. Lushchak VI (1993). Free and bound pyruvate kinase from fish brain: properties and redistribution after hypoxia. Biochemistry and Molecular Biology International, 29:
1103-1109.

12. Brooks SPJ \& Storey KB (1993). Control of glycolytic enzyme binding: effect of changing enzyme substrate concentrations on in vivo enzyme distribution. Molecular and Cellular Biochemistry, 122: 17.

13. Lushchak VI (1991). Properties of membrane-bound lactate dehydrogenase from white skate muscle. Biokhimiya, 56: 21732180.

14. Brooks SPJ \& Storey KB (1988). Subcellular enzyme binding in glycolytic control: in vivo studies with fish muscle. American J ournal of Physiology, 255: R289-R294.

15. Knull HR (1990). Compartmentation of glycolytic enzymes in the brain and association with the cytoskeletal proteins actin and tubulin. In: Structural and Organizational Aspects of Metabolic Regulation. Alan R. Liss, Inc., New York, 215-228.

16. Clarke FM, Shaw FD \& Morton DJ (1980). Effect of electrical stimulation post mortum of bovine muscle on the binding 
of glycolytic enzymes. Functional and structural implications. Biochemical J ournal, 186: 105-109.

17. Brooks SPJ \& Storey KB (1991). Studies on the regulation of enzyme binding during anoxia in isolated tissues of Busycon canaliculatum. J ournal of Experimental Biology, 156: 467-481.

18. Duncan J A \& Storey KB (1991). Role of enzyme binding in muscle metabolism of the goldfish. Canadian J oumal of Zoology, 69: 1571-1576.

19. Lushchak VI \& Storey KB (1994). Effect of exercise on the distribution of enzymes in trout white muscle and kinetic properties of AMP-deaminase from free and bound fractions. Fish Physiology and Biochemistry, 13: 226-239.

20. Van den Thillart G, Kesbeke $F$ \& Van Waarde A (1980). Anaerobic energy-metabolism of goldfish Carassius auratus (L.). Influence of hypoxia and anoxia on phosphorylated compounds and glycogen. J oumal of Comparative Physiology, 136: 45-52.

21. Van den Thillart $G \&$ Van Waarde $A$ (1985). Teleosts in hypoxia: aspects of anaerobic metabolism. Molecular Physiology, 8: 393-409.

22. J ohnston IA (1975). Anaerobic metabolism in the carp (Carassius carassius L.). Comparative Biochemistry and Physiology, 51B: 235-241.
23. J orgensen J B \& Mustafa T (1980). The effect of hypoxia on carbohydrate metabolism in flounder (Platichthys flesus L.). I. Utilization of glycogen and accumulation of glycolytic end products in various tissues. Comparative Biochemistry and Physiology, 67B: 243-248.

24. J orgensen J B \& Mustafa T (1980). The effect of hypoxia on carbohydrate metabolism in flounder (Platichthys flesus L.). II. High energy phosphate compounds and the role of glycolytic and gluconeogenic enzymes. Comparative Biochemistry and Physiology, 67B: 249-256.

25. Lushchak VI, Rusinova OS, Astachova LP, Kondrat'jeva TP \& Rudenko LM (1997). The influence of hypoxia on the carbohydrate metabolism in brain and liver of European red mullet. J oumal of Evolutionary Biochemistry and Physiology, 33: 38-43.

26. Van den Thillart G (1982). Adaptations of fish energy metabolism to hypoxia and anoxia. Molecular Physiology, 2: 49-61.

27. Via JD, Van den Thillart $G \&$ Cattani $O$ (1993). Intermediary metabolism and critical levels of hypoxia in the Adriatic sole Solea solea. Biologica Marina, 1 (Suppl Notiziario della Societa Italiana di Biologia Marina): 109-113.

28. Van Waarde A, Van den Thillart $G \&$ Kesbeke $F$ (1983). Anaerobic energy metabolism of the European eel, Anguilla anguilla L. J ournal of Comparative Physi- ology, 149: 469-475.

29. Storey KB (1988). Suspended animation: the molecular basis of metabolic depression. Canadian J ournal of Zoology, 66: 124-132.

30. Severin SE \& Solov'eva GA (1989). Practical Works in Biochemistry. MSU Press, Moscow.

31. Ferguson RA \& Storey KB (1991). Glycolytic and associated enzymes of rainbow trout (Oncorhynchus mykiss) red cells: in vitro and in vivo studies. J ournal of Experimental Biology, 155: 469-485.

32. Hochachka PW \& Somero GN (1984). Biochemical Adaptation. Princeton University Press, Princeton, NJ .

33. Storey KB (1987). Tissue-specific controls on carbohydrate catabolism during anoxia in goldfish. Physiological Zoology, 60: 601607.

34. Van den Thillart $\mathrm{G} \&$ Smit H (1984). Carbohydrate metabolism of goldfish (Carassius auratus L.). Effects of long-term hypoxiaacclimation on enzyme pattems of red muscle, white muscle and liver. J ournal of Comparative Physiology. B, 154: 477486.

35. Kurganov BI (1985). Control of enzyme activity in reversibly adsorptive enzyme systems. In: Welch GR (Editor), Organized Multienzyme Systems: Catalytic Properties. Academic Press, New York, 241-270. 


\section{Brazilian Journal of Medical and Biological Research}

on the

Internet

\section{Available at}

http://www.epub.org.br/bjmbr/ http://www.scielo.br/ 